\title{
ROBIN HOOD AND THE FOREST LAWS
}

\author{
Stephen Knight \\ The University of Melbourne
}

The routine opening for a Robin Hood film or novel shows a peasant being harassed for breaking the forest laws by the brutal, and usually Norman, authorities. Robin, noble in both social and behavioral senses, protects the peasant, and offends the authorities. So the hero takes to the forest with the faithful peasant for a life of manly companionship and liberal resistance, at least until King Richard returns and reinstates Robin for his loyalty to true values, social and royal, which are somehow congruent with his forest freedom.

The story makes us moderns feel those values are age-old. But this is not the case. The modern default opening is not part of the early tradition. Its source appears to be the very well-known and influential Robin Hood and his Merry Men by Henry Gilbert (1912). The apparent lack of interest in the forest laws theme in the early ballads might simply be taken as reality: Barbara A. Hanawalt sees a strong fit between the early Robin Hood poems and contemporary outlaw actuality. Her detailed analysis of what outlaws actually did against the law indicates that robbery and assault were normal and that breach of the forest laws was never an issue. ${ }^{1}$

The forest laws themselves are certainly medieval. ${ }^{2}$ They were famously imposed by the Norman kings, they harassed ordinary people, stopping them using the forests for their animals and as a source for food and timber, and Sherwood was one of the most aggressively policed forests - but this did not cross into the early Robin Hood materials. Robin versus the forest laws is a fairly recent emphasis, with postmedieval causes and contexts that will be explored here. But this is not one of those cases where a feature suddenly enters the tradition, like Robin being a displaced lord, or, much later, a Saxon patriot. Killing the king's deer is in fact referred to at times in the early tradition, but it has no thematic emphasis or continuity as a motif: there are certain explicit conditions, around and after 1800, under which it becomes of compelling interest and is then narrativized as the reason for Robin's outlaw status because the forest laws are taken as symbolic of general authoritarian oppression.

The most marked feature of the forest in the early texts is a utopian feeling. At the opening of the earliest surviving ballad, Robin Hood and the Monk, it is early summer, and everything is lovely:

In somer when pe shawes be sheyne

And leves be large and long

Hit is full mery in feyre foreste

To here pe foulys song

\footnotetext{
1 Barbara A. Hanawalt, "Ballads and Bandits: Fourteenth-Century Outlaws and the Robin Hood Poems,” in Chaucer's England: Literature in Historical Context, ed. Barbara A. Hanawalt, Medieval Studies at Minnesota 4 (Minneapolis: University of Minnesota Press, 1992), 154-75.

${ }^{2}$ See Raymond Grant, The Royal Forests of England (Sutton: Phoenix Mill, 1991).
} 
To se the dere draw to pe dale

And leve the hilles hee

And shadow hem in pe leves grene

vndur the grene wode tre $(1-8)^{3}$

In a way this is realistic - outlaws normally only went to the forest in summer. But the summer magic is crucial—and though only touched in, it is structural. In his other, non-outlaw identity Robin Hood is the leader of celebrations of early summer in what are called the "play-games," found in the English south-west, and later in Scotland, he rides through the small town from the forest to lead a celebration and collect moneywithout menaces - for civic needs like roads or the church tower. Robin is linked to nature: he can be called a hero of natural law in every sense.

His enemies are unnatural practitioners of law both in the state- the sheriff; and in the equally powerful church - the abbot, the bishop and the monks. Typically the outlaws rob them while they are on the way through the forest, where they are dangerously entering Robin's domain. In the same way the major early stories show the sheriff being humiliated in the forest, even, after being particularly bad, being shot in the head by Little John as he tries to run away to the safety of Nottingham in Robin Hood and Guy of Gisborne (by 1640).

Most modern readings do not see any difference between these figures who controlled ordinary life in the towns and the agents of forest law, usually called foresters. The very influential F. J. Child, whose late nineteenth-century edition, with commentary on each ballad, was the only substantial work on the outlaw tradition until the modern period, says in his headnote to the Gest of Robin Hood, of c. 1500, that Robin "lives by the king's deer" and that "Bishops, sheriffs and game-keepers [were] the only enemies he ever had." 4

But these three opponents are not equal in the early texts. In the Gest the feast the outlaws give the knight includes venison, with has presumably been poached before it was roasted, but this is not an important enough matter to be specified. When the king originally went off looking for Robin Hood in Plomton Park he found the antlered deer gone, but stealing the deer was not the reason he was looking for Robin: it was his habitual theft of money, from important people like the sheriff and the monks.

The Gest acknowledges some breach of the forest laws when an outlaw says "We lyue by oure kynges dere" (1489) $)^{5}$ but in the other early texts this theme is almost completely absent. In Robin Hood and the Monk they eat "pastes of venyson' (324) but the text has no other reference, even of this very limited sort, to the forest laws.

\footnotetext{
${ }^{3}$ Robin Hood and the Monk in Thomas H. Ohlgren and Lister M. Matheson, ed., Early Rymes of Robyn Hood: An Edition of the Texts, ca. 1425 to ca. 1600, Medieval and Renaissance Texts and Studies 428 (Tempe: Arizona Center for Medieval and Renaissance Studies, 2013), 3-17. Further references to this and all other Robin Hood texts, after an initial note citation, will be given parenthetically.

${ }^{4}$ F. J. Child, ed., The English and Scottish Popular Ballads, 5 vols. (New York: Dover, 1965), 3:42.

${ }^{5}$ Cited from the Wynkyn de Worde edition of A Lytell Geste of Robyn Hode, in Ohlgren and Matheson, Early Rymes, 89-147.
}

The Bulletin of the International Association for Robin Hood Studies 1 (2017): 1-14. 
As the tradition becomes both increasingly popular and also much better recorded in the seventeenth century, there are occasional almost casual references to deer. Michael Drayton’s Polyolbion, the 1612 version, says in its Sherwood sequence:

And of those Archers braue, there was not any one But he could kill a Deere his swiftest speed upon (339-40). ${ }^{6}$

The broadside ballads follow the same style. In Robin Hood's Fishing (c.1650) Robin is weary of "chasing of the fallow deer" (8). In Robin Hood and Maid Marian (1660 or later) John goes off “To kill the deer" (60) to celebrate the lover's union. In the conservative semi-epic ballad A True Tale of Robin Hood (1632) there is one mention of them eating "venyson fat and good" (162) in the forest, but nothing more on the topic: the poem is anxious only about Robin Hood's danger to the state. ${ }^{7}$

There does in the seventeenth century seem to be a growth in the awareness that Robin Hood was resisting the forest laws. Some of these references are merely to the activity of poaching itself: in the popular Robin Hood and Little John (c.1656) Robin says to John "I'll teach the use of the bow / To shoot at the fat fallow-deer," (108-109) but some go further and knowingly imagine a forest laws conflict. In Robin Hood Rescues Three Young Men ("Beggar" version, c.1656) the men are condemned to death for "slaying the king's fallow deer" (23), but Robin rescues them. ${ }^{8}$

Even when forest laws are acknowledged, the situation is not simple. In Robin Hood and the Tanner (1657), the deer are mentioned early on, as the outlaws "view the red deer, that range here and there" (3.3). Then the Tanner actually pretends to be "a keeper of the forest"-but this is only a pretext for a fight with Robin, not some legal activity. In Robin Hood and the Tinker (1657) the Tinker does agree to go bounty-hunting for Robin Hood, and he is told Robin is off "Killing of the kings deer" (27.4). But he too fights cheerfully with Robin and is incorporated into the forest community. In Robin Hood and the Ranger (c.1740), the ranger is a genuine forester, and Robin is off "to kill a fat buck" (3.1), but again after they fight they become allies. The forest laws motif in these is just a plot mechanism helping to develop the community-forming narrative of the "Robin Hood meets his match" ballads. ${ }^{9}$

There is one much stronger seventeenth-century Robin versus forester story, Robin Hood's Progress to Nottingham (c.1650). Teenage Robin is going to an archery contest and meets fifteen foresters. One sneers at a boy with a bow: Robin bets him he can "hit a mark a hundred rod, / And I'le cause a hart to dye" (21-22) ${ }^{10}$ _and does so.

\footnotetext{
6 Michael Drayton, “Song 26” in Poly-Olbion, in The Works, ed. J. W. Hebel, 6 vols. (Oxford: Blackwell, 1961), 4:123.

${ }^{7}$ Robin Hood's Fishing, Robin Hood and Maid Marian, and A True Tale of Robin Hood in Stephen Knight and Thomas Ohlgren, ed., Robin Hood and Other Outlaw Tales, 2nd ed. TEAMS Middle English Texts Series (Kalamazoo: Medieval Institute Publications, 2000), 581-91, 493-98, and 602-25.

${ }^{8}$ Robin Hood and Little John and Robin Hood Rescues Three Young Men in Knight and Ohlgren, 47685, and 513-20.

${ }^{9}$ Robin Hood and the Tanner, Robin Hood and the Tinker, and Robin Hood and the Ranger, in Child, 137-40, 140-43, and 152, lines noted by stanza and line number.

10 Robin Hood and his Progress to Nottingham, in Knight and Ohlgren, 507-12.
} 
The forester refuses to pay and threatens Robin, so he runs off, turns, shoots the forester dead, and also kills his fourteen friends. Then for the first time he takes to the forest. This startling ballad was extremely popular, but it is not really a forest law story, just a bad foresters story. Essentially it is part of the international hero myth, explaining how the hero faced his first challenge-it is not in any real way an account of or challenge to the forest laws.

That very violent Robin perhaps meshes with the few early seventeenth century references that Christopher Hill found, and he argued that in them Robin was representing the parliamentary turn to violence of the period. ${ }^{11}$ The connection certainly seems behind the decision to stage in Nottingham on King Charles II's day of accession a very short play entitled Robin Hood and his Crew of Souldiers. The forest is overwhelmed with a shout of acclamation for the king, and though Little John demurs, saying "Every brave soule is born a King," Robin without resistance or even action bows to the new kingly authority. ${ }^{12}$ This is royal laws, not forest laws.

A different link had emerged between Robin and the forest in the sixteenth century when the hero was gentrified. Early Robin is a yeoman, and he lives vaguely here and now - a king Edward is mentioned in the Gest, but he is not given a number and so could be anywhere in the preceding two hundred years. The tightening ideology and state control of the Tudor period did not leave Robin untouched. The summer-celebrating play-games were often banned as likely to get out of orderly hand, and in a potent piece of appropriation Robin was reconceived as a lord fallen on hard times, exiled by a bad king. This is where King John steps into the tradition and the 1190s become the default Robin Hood date.

In 1598-99 Anthony Munday wrote two plays-The Downfall of Robert Earl of Huntington and The Death of the same. Being in the forest is now his "downfall" not his natural utopian state. But he still likes it there, and there is nature-celebration poetry: Lord Robert describes their changed situation to Lady Matilda, known in the forest as Marian:

For Arras hangings and rich Tapestrie,

We have sweete natures best imbrothery.

For thy steele glass, wherin thou wontst to looke,

Thy christall eyes gaze in a christall brooke.

At court, a flower or two did decke thy head:

Now with whole garlands is it circled.

For what in wealth we had, we have in flowers,

And what we loose in halles, we find in bowers. (1374-81) ${ }^{13}$

This is gentry pastoral gardening, not an encounter with the forest, and Munday seems positively to distance Robin from improper hunting. There is "venson" in the forest

\footnotetext{
${ }^{11}$ Christopher Hill, Liberty Against the Law: Some Seventeenth-Century Controversies (London: Lane, 1996), 71-82.

${ }^{12}$ For discussion and text see Stephen Knight, "Robin Hood and the Royal Restoration," Critical Survey 5 (1993): 298-312.

${ }^{13}$ Anthony Munday, The Downfall of Robert, Earle of Huntington, in Knight and Ohlgren, 303-401.
} 
(1518) but as Little John notes to the Friar (or rather, in the para-play, Sir John Eltham to Skelton) there has been "no hunting song, no coursing of the buck" (2213). Though Scathlock and Scarlock, the widow's sons, are rescued from execution by the sheriff, there is no forest law reason for their intended fate - unlike in the later ballad version. When the King arrives there is no mention of breaking the forest laws, and then in the sequel play The Death, the King and Robin go hunting together.

Cultural gentrification to the exclusion of the forest law theme, or any real kind of resistance, is central to the fine but unfinished masque The Sad Shepherd, which Ben Jonson seems to have been working on late in life in the 1630s. His prologue insists this is an English version of classical pastoral, being about "mere English Flocks," and when Robin welcomes visitors to Sherwood, including the sad shepherd himself, the gloomy lover who has stolen the title from him, he greets them in the unproblematic "Jolly Bower / Of Robin-hood and to the greene-wood Walkes." 14

With the two exceptional and contextual formations of violent ballads and gentrified pastoral, until the eighteenth century Robin's forest is a Utopian base for a critique of social and legal mismanagement. This continues in the popular prose and verse pamphlets often named The Life of Robin Hood, and while there is some increment of forest laws references, there is no focus on challenging them as Robin's role in life. In the 1678 prose Noble Birth, as part of "Robin Hood's Delight” he fights against "keepers of the King's game" and the author retells the potentially forest lawlinked stories of Robin Hood and the Tanner and Robin Hood and Three Young Men. The Whole Life of 1712 does not advance on this, but Captain Alexander Smith's prose account of 1714 tells the Robin Hood's Progress to Nottingham story with a difference. The foresters disliked the ordinary people and "owed them a grudge, for always endeavouring to kill any of the King's deer.” 15 This moves the story forward into Robin's adult life, necessarily breaking forest laws with his men. But in other comparable texts the forest laws idea is not a straightforward challenge to authority. In the 1734 Life by Captain Johnson, Robin is not only the son of the Earl of Huntington, but his father was Head Ranger in the north of England, a motif which recurs in nineteenth-century Robin Hood novels. There is one ballad that does this sort of work: the rifacimento ballad Robin Hood's Birth, Breeding, Valour and Marriage (1681-84). Robin's father was a forester, but still, like his mother, of gentry stock and the hero, now part of the gentry at Gamwell Hall, can go hunting with John, his servant. Robin says "Bid my yeomen kill six brace of bucks," and then they have to fight off some yeomen who want to take the bucks from him (159). ${ }^{16}$ It is forest laws from the authoritarian side, now gentrification has taken control of Robin.

\footnotetext{
14 Ben Jonson, The Sad Shepherd, in The Cambridge Edition of the Works of Ben Jonson, David Bevington, Martin Butler, and Ian Donaldson, ed., 7 vols. (Cambridge: Cambridge University Press, 2012), 7:417-80, Act I, scene iv, lines 3-4.

15 The Noble Birth of Robin Hood (London: Vere, 1678), unpaginated; Captain Alexander Smith, "Robin Hood," in A Complete History of the Lives and Robberies of the Most Notorious Highwaymen, ed. Arthur L. Hayward (London: Routledge, 1926), 408-12 at 409.

${ }^{16}$ Robin Hood's Birth, Breeding, Valour and Marriage, in Knight and Ohlgren, 527-40.
} 
Though the forest laws theme is evanescent and at most of limited instrumental weight in the early Robin Hood texts, there had been plenty of medieval awareness of the impact and brutality of the forest laws. For many people, Magna Carta had itself become associated with freedom to use forest and waste land: this idea in fact went back to the 1217 Charter of the Forest, which was confirmed in 1297 specifically as a companion to Magna Carta by King Edward I. It placed limits on the power of the crown to exploit forests for its profit and its pleasure in hunting, and permitted some use of forest and waste land by common people.

From the sixteenth century on this sense of exploitative control of natural resources-expressed strongly, at least with reference to the middle ages, by Pope in "Windsor Forest" (1713), merged with the resistance to the enclosure movement-but without any trace of Robin Hood. In the 1730s when the Hampshire "blacks," disguised peasants, were invading newly enclosed forest land they had a mythical leader, but as E. P. Thompson notes, although he was like Robin Hood in many ways his name was actually "King John"-presumably a reference to the Magna Carta link to the forest laws. ${ }^{17}$ And then in 1765 when royalty enclosed Richmond Park in 1765, it was not Robin Hood who was associated with the resistance, but Merlin. No doubt because the Merlin's Cave Queen Caroline had built there in 1735 had just been destroyed as part of Capability Brown's maneuvers, which included the enclosure itself. Merlin was held to have predicted both this and the civil resistance, which included breaking into the park in daylight to walk about and use it.

This neutral position on Robin and the forest laws lasts a long time. The introduction to Joseph Ritson's very widely-read 1795 edition of the ballads, though firmly against the medieval church and aristocracy, merely says that "In these forests and with this company he for many years reigned to be an independant [sic] sovereign" and the "forests were, in short, his territory." ${ }^{18}$ Recognizing the medieval origin of the forest, Ritson says "The deer with which the royal forests then abounded (every Norman tyrant being, like Nimrod, 'a mighty hunter before the Lord') would afford our hero and his companions an ample supply of food throughout the year" (vivii). But there is no mention of the outlaws breaching forest laws, and indeed they are finally called "our foresters" (vii).

However, Robin does before long firmly enter the area of forest law resistance, even come to dominate it, and in large part through the later part of the process of enclosure. The entry point is Thomas Love Peacock, but not his 1822 novel Maid Marian. Rather it is his Calidore and Miscellanea, a posthumous collection of 1891 edited by Richard Garnett, which published for the first time Peacock's late essay “The Last Day of Windsor Forest.” Here he reminisces about living on the edge of the forest at Egham, and his theme is the enclosure of the forest by George IV. The act went through Parliament in July 1814, says Peacock, though it appears to have been in fact 1813. Local people were angry at being excluded from the forest and in

\footnotetext{
${ }^{17}$ E. P. Thompson, Whigs and Hunters: The Origin of the Black Act (London: Allen Lane, 1975), see Chapter 5, “King John,” 142-46.

${ }^{18}$ Joseph Ritson, "The Life of Robin Hood," in Robin Hood, A Collection of All the Ancient Poems, Songs and Ballads Now Extant Relative to the Celebrated English Outlaw, 2 vols. (London: Egerton and Johnson, 1795), 1:i-xiv at vi.
} 
particular from being forbidden from "hunting, coursing, killing, destroying, or taking any Deer whatsoever within the same” (150). Some locals thought the act was badly drafted, and claimed they could still hunt in the park. The leader of this resistance was a farmer from Water Oakley. Peacock has forgotten his name, but not his pseudonym. It was Robin Hood. He "taking with him two of his men, whom he called Scarlet and Little John sallied forth daily into the forest to kill the King's deer, and returned home every evening loaded with spoil” (150). Peacock continues “One day I was walking towards the Dingle, when I met a man with a gun, who asked me if I had seen Robin Hood? He told me he was Scarlet. He was a pleasant-looking man, and seemed as merry as his original: like one in high enjoyment of sport” (151).

Peacock was a fiction-writer of course; maybe he invented the incident. But not the general story - it is described in Hughes's History of Windsor Forest and the essay by Rob Gossedge, ${ }^{19}$ which put the enclosure and the resistance in the context of an extended struggle between the crown and the locals over access to the forest and its produce. As Gossedge has argued, ${ }^{20}$ Peacock's account appears to have been the stimulus for his own Maid Marian, started not long after this in 1818, but not finished and published until 1822. It is not, Gossedge says "a novel about enclosures" (160), but it thematizes the issues, being "very much concerned with the disappearing forest society, its replacement by officials, and the lingering resistance of yeomen and labourers”' (160). Like Scott in Ivanhoe, Peacock insists on Robin's right to rule in the forest: Friar Tuck's long sermon on Right versus Might asks "What title had William of Normandy to England that Robin of Locksley has not to merry Sherwood" (163) — which clearly refers to William I's role as the creator of the forest laws.

There seems to have been growing contiguity between Robin Hood and the second phase of the enclosure movement. From the sixteenth century until the earlymid eighteenth century, in the first phase, enclosures were by local agreement-i.e. the lords persuaded or forced people to give up their traditional rights and very often to move. Some historians call it enclosure by consent, but there was plenty of dissent as recorded in E. P. Thompson's Whigs and Hunters - but not with Robin as a symbolic leader. It appears to have been the parliamentary enclosures which stimulated the new intensity of the forest law material in the Robin Hood tradition. The enclosure dissenters picked up on his meaning as a figure of the people resisting official brutality, but this process of dissent and Robin Hood involvement only became common in the second half of the eighteenth century and had uneven distribution across Britain. The acts mostly applied to areas in the north and west, the best lands having already been enclosed by the lords via consent, and there is little sign that Robin Hood was associated in any way strongly with the south, the South Midlands and East Anglia, the earlier, consent enclosure, areas. The parliamentary acts were mostly to do with forest and wild enclosures, those used for hunting, while

19 G. M. Hughes, The History of Windsor Forest (London: Ballantyne, 1890), 83-5; see also 138-44 in Rob Gossedge, “Thomas Love Peacock, Robin Hood and the Enclosure of Windsor Forest,” in Robin Hood in Greenwood Stood: Alterity and Context in the English Outlaw Tradition, ed. Stephen Knight, Medieval Identities: Socio-Cultural Spaces 1 (Turnhout: Brepols, 2012), 135-64.

${ }^{20}$ See Gossedge, especially 158-64. 
the earlier allegedly consentual reclamation dealt mostly with the previously common village fields, where Robin Hood had no meaning.

But there is another major force at work-Romanticism. Robin comes to represent a medievalized sense of the value of nature in a time of urbanization and growing capitalism. The first sign of Robin as a spirit of the forest is when Keats and his friend Reynolds exchanged poems about the outlaw. Reynolds' third sonnet is his best, after receiving Keats' own ode in response to his first two sonnets. As a result of this early example of Creative Writing by distance, Reynolds, in "To E-," addressing his fiancée, says of the outlaw myth:

It tells a tale of forest days—of times

That would have been most precious unto thee,-

Days of undying pastoral liberty!

Sweeter than music of old abbey chimes,-

Sweet as the virtue of Shakespearean rhymes.-

Days shadowy with the magic greenwood tree! ${ }^{21}$

Reynolds' cultural medievalism is liberal, but also basically idealistic. Keats was tougher, remembering not just the glamor of the forest, but deploring its modern degradation. If Robin now had again his "forest days"-Reynolds in his third sonnet will pick up the phrase-

He would swear, for all his oaks, Fall'n beneath the dockyard strokes, Have rotted on the briny seas; (44-45)

And if Marian were here

She would weep that her wild bees

Sang not to her-strange that honey

Can't be got without hard money! (46-48)

This refers to a widely discussed modern feature of enclosure-the removal of tenants' rights to enjoy natural produce upon their land without extra payment for it.

Robin the spirit of the forest meshed easily with the idea of resistance to the forest laws. Peacock's Maid Marian is the major basic statement of the link. But it is assumed when in Ivanhoe (1819) Scott sees Robin as lord of the forest and says "the charter of the Forest was extorted from the unwilling hands of King John.”22

21 On the Keats-Reynolds exchange see John Barnard, “Keats’s 'Robin Hood,' John Hamilton Reynolds, and the 'Old Poets,"' in Robin Hood: An Anthology of Scholarship and Criticism, ed. Stephen Knight (Cambridge: D. S. Brewer, 1999), 123-40 at 134-35. All quotations from Keats’ poetry are drawn from Jack Stillinger, ed., The Poems of John Keats (Cambridge, MA: Harvard University Press, 1978).

${ }^{22}$ Walter Scott, Ivanhoe (London, Penguin, 1972), 314.

The Bulletin of the International Association for Robin Hood Studies 1 (2017): 1-14. 
The new impact of Robin as the spirit of the woods is clear in the change from the Thomas Bewick's title-page illustration in Ritson's 1795 first edition to the one that emerged in the second edition-but not at first. When this edition appeared in 1820 it retained Robin boldly fighting the tanner on the title-page but, intriguingly, in the 1823 reprint the trouble had been taken to replace this with a pensive Robin, seated by a tree, with bow, sword and shield inactive, while a deer runs through the forest behind him. ${ }^{23}$

Romantic Robin could also be anti-forest laws Robin. This new mix, forest lord and forest laws resister, now became the default Robin Hood. Leigh Hunt, who knew Keats well, seems likely to have been stimulated by Peacock, as well as Ritson and conceivably Scott, to write four Robin Hood ballads, first published in 1820 in The Indicator and then reprinted, with the subtitle "(for children)" emerging in a 1855 edition. The second, Robin Hood's Flight, which reworks the story of Robin Hood's Progress to Nottingham, has a strong forest laws theme. First Robin recognizes royal appropriation:

And then bold Robin he thought of the King

How he got all this forests and deer,

And how he made the hungry swing

If they killed but one in the year. ${ }^{24}$

Robin meets the starving Will: he shoots a deer to feed him; the Abbot and three foresters arrive to arrest him. Robin kills the Abbot and two foresters but the third one joins him and Will and they go off to the forest together. A neat condensation of motifs from three ballads - hostile foresters, a bad Abbot and Robin's adventures with two others in the forest-and combining Hunt's hostility to royalty and the church, this may well be the ultimate source for the "Robin rescues a deer-killing peasant" opening so popular via Henry Gilbert in the twentieth century as a reason for his outlawry.

In the Victorian popular Robin Hood novels, the forest laws theme is normal. There is plenty of resistant material in the first major one, Royston Gower (1838) by the Chartist Thomas Miller, who states in his introduction "the principal intention of this work is to show the tyranny of the Norman Forest Laws." 25 The Norman-Saxon divide is strong, though there are some admirable Normans whom Robin and his men help, but the ethnic opposition is strongly linked throughout to the forest laws theme. The Romantic idea of the forest is also strong - after rescuing Hereward the noble Saxon, the outlaws return to the forest in delight and Robin says "Let me be the

\footnotetext{
23 See Stephen Knight, Robin Hood: A Mythic Biography (Ithaca: Cornell University Press, 2003), 125 and 126 for the two illustrations.

${ }^{24}$ Leigh Hunt, Selected Writings of Leigh Hunt, gen. ed. Michael Eberle-Sinatra and Robert Morrison, 6 vols. Vol. 5, Poetical Works, 1801-1821, ed. John Strachan (London: Pickering and Chatto, 2003), 5: 291-4. See 5:292, lines 33-36.

${ }^{25}$ Thomas Miller Royston Gower, or the Days of King John, 3 vols. (London: Colburn, 1838), 1:xiv.
}

The Bulletin of the International Association for Robin Hood Studies 1 (2017): 1-14. 
captive of green trees, and my prison-house walled in with the rustling foliage of summer,"26

Most of the outlaw novels are less serious, and usually vague about the forest laws, but retain the forest context in various ways. Pierce Egan's Robin Hood and Little John (the serial started in 1838, the novel appeared in 1840) has a final celebration scene drawn from Ivanhoe and early on a less traditional scene with the tree-linked ghost of the sister of Robin's foster-father-who is a forester, though a very friendly one. The often humorous Joachim Stocqueler in his 1849 Maid Marian: the Forest Queen has the brave heroine running the show while Robin is on crusade, and early on she is assaulted in the dark forest by a disguised Prince John, but her brave dog comes to her rescue. Things drift further in the 1869 Robin Hood and the Adventures of Merrie Sherwood published by George Emmett in The Young Englishman's library, where Robin has an entirely friendly encounter with a Wood Demon.

But Victorian forest Robin could be more focused on ideals and forest laws. Alfred Tennyson's The Foresters (1891) seems to be heading for an encounter with the forest laws theme when Robin, as a partial explanation of his sudden outlawing says "I have sheltered some that broke the forest laws." 27 The king does also say before pardoning Robin that he has "broken all our Norman forest-laws / And scruplest not to flaunt it to our face” (780). But nothing is made of this in the narrative: Tennyson swerves from anti-forest laws Robin to Romantic Robin, and Marian has a fine late speech, mostly idealistic medievalism but retaining some sense of liberal ideas:

... I think these oaks at dawn and even,

Or in the balmy breathings of the night

Will whisper evermore of Robin Hood. (782)

Then she assesses their achievement:

We leave but happy memories to the forest.

We dealt in the wild justice of the woods.

All those poor serfs whom we have served will bless us,

All those pale mouths which we have fed will praise us-

All widows we have holpen pray for us ... (782)

Modern Robin is for the most part an improbable but consolatory mix of qualities-in some way noble, he is also a friend of the poor and so charity replaces radical action. He is also a representative of the Saxons, but only really against the wicked French barons - an idea which emerges in Scott right after the Napoleonic war. But the idea that his outlaw band resisted oppressive and exploitative laws is available and can at times have a firm presence, as in Henry Gilbert's influential 1912 novel, or the

\footnotetext{
${ }^{26}$ Ibid., 3:191.

${ }^{27}$ Alfred Tennyson, The Foresters, in Poems and Plays, Oxford Standard Authors (Oxford: Oxford University Press, 1965), 748-82 at 756.
}

The Bulletin of the International Association for Robin Hood Studies 1 (2017): 1-14. 
unusual 1934 Bows Against the Barons by Geoffrey Trease. Here a boy is caught killing a deer and Robin acts to rescue him from jail with what the chapter title calls "The Comrades of the Forest"-the wording is deliberate, and finally Robin announces "It was hammers and sickles did it today, not the bows and bills of Sherwood." 28 That sense of resistance to oppressive law in general, not only that of the forest, has recurred-a notable example is Theresa Tomlinson's trilogy The Forestwife (2003), historicist feminism aimed at teenagers, where a vigorous young woman, assisted by a handsome but less than intelligent Robin, basically becomes involved in the Peasants' Revolt of 1381.

Film and television have unsurprisingly been less radical. "Sherwood Forest" has been in the title of quite a number of films, but most of those are from 1946 to 1960, and it seems likely that they were trying to elude in title the dominant impact of the 1938 Warners classic. There Robin is a dashing action hero but the film is also rich in natural-forest references - the tree that comes to life with camouflaged outlaws is hard to forget - and there is also some element of radicalism, starting with the forest laws opening as Robin rescues a peasant, which replaces the grand joust and court beginning of the 1922 Fairbanks film. The politics are mostly general, with Robin, as he says, the voice "of all free men," but they can be sharper: the Normans are clearly played like Brownshirt thugs, and Warners were very aware their Berlin agent had been beaten to death in 1935 for being Jewish.

A comparable politics was to be found in the long-lasting and immensely popular British TV series beginning in 1955. Richard Greene, playing the part as what might be called Squadron Leader Robin Hood, is back from the war, facing the historical crimes of the officials of England-much like a new Labour MP from the 1945 elected government. If the series had a leftist edge including forest laws, there was a source. Hannah Bernstein, the American producer, herself a political refugee from New York, knew where to get good writing cheap-much of the early part of the series was written by Americans black-listed outlaws under McCarthyism, including Ring Lardner, Jr., and Ian McLellan Hunter.

The forest as both idyllic home and also refuge for those resisting oppression was strongly realized in the 1980s television series Robin of Sherwood, with a very glamorous Robin and Marian, but also a recurrently political script, in part forest laws, in part just anti-Thatcher. That did so well in the USA that two films were made in 1991, neither of them with much forest laws interest or radical edge, though the recent television series starring Jonas Armstrong combines a return from overseas war theme-pretty clearly post-Iraq — with a fairly mild theme about oppressive laws, including those of the forest. The most recent film, starring Russell Crowe in 2010, returns to the nineteenth-century theme of a medieval prolepsis of modern democracy, as it involves Robin in pre-Magna Carta activities that mesh with resistance to forest laws.

The way the figure of Robin Hood developed after 1800 seems to be a classic of dialectical medievalism: through forest celebration it yearns for the natural beauties of pre-urban, pre-capitalist times; but through the forest laws concept it also stands for an equally modern sense of personal freedom and escape from the unpleasant

${ }^{28}$ Geoffrey Trease, Bows Against the Barons (London: Lawrence, 1934), 61. 
interventions of authority. Well-armed, with a loyal band, in the summer forest, close to the oppressive town, Robin Hood moved relatively recently into resisting the forest laws, one of the many indications how he and his myth keep on evolving in the service of our considerations and our consolations. 


\section{BIBLIOGRAPHY}

Barnard, John. “Keats's 'Robin Hood,' John Hamilton Reynolds, and the 'Old Poets.”' In Robin Hood: An Anthology of Scholarship and Criticism, edited by Stephen Knight, 123-40. Cambridge: D. S. Brewer, 1999.

Child, F. J., ed. The English and Scottish Popular Ballads. 5 vols. New York: Dover, 1965.

Drayton, Michael. The Works, edited by J. W. Hebel. 6 vols. Oxford: Blackwell, 1961.

Gossedge, Rob. "Thomas Love Peacock, Robin Hood and the Enclosure of Windsor Forest." In Robin Hood in Greenwood Stood: Alterity and Context in the English Outlaw Tradition, edited by Stephen Knight, 135-64. Medieval Identities: Socio-Cultural Spaces 1. Turnhout: Brepols, 2012.

Grant, Raymond. The Royal Forests of England. Sutton: Phoenix Mill, 1991.

Hanawalt, Barbara A. "Ballads and Bandits: Fourteenth-Century Outlaws and the Robin Hood Poems.” In Chaucer's England: Literature in Historical Context, edited by Barbara A. Hanawalt, 154-75. Medieval Studies at Minnesota 4. Minneapolis: University of Minnesota Press, 1992.

Hill, Christopher. Liberty Against the Law: Some Seventeenth-Century Controversies. London: Lane, 1996.

Hughes, G. M. The History of Windsor Forest. London: Ballantyne, 1890.

Hunt, Leigh. Selected Writings of Leigh Hunt, gen. ed. Michael Eberle-Sinatra and Robert Morrison, 6 vols. Vol. 5, Poetical Works, 1801-1821, ed. John Strachan. London: Pickering and Chatto, 2003.

Jonson, Ben. The Cambridge Edition of the Works of Ben Jonson, edited by David Bevington, Martin Butler, and Ian Donaldson. Vol. 7, 1641. Cambridge: Cambridge University Press, 2012.

Knight, Stephen. Robin Hood: A Mythic Biography. Ithaca: Cornell University Press, 2003.

. "Robin Hood and the Royal Restoration.” Critical Survey 5 (1993): 298-312.

Knight, Stephen, and Thomas Ohlgren, ed. Robin Hood and Other Outlaw Tales. 2nd ed. TEAMS Middle English Texts Series. Kalamazoo: Medieval Institute Publications, 2000.

Miller, Thomas. Royston Gower, or the Days of King John. 3 vols. London: Colburn, 1838.

The Noble Birth of Robin Hood. London: Vere, 1678.

Ohlgren, Thomas H., and Lister M. Matheson, ed. Early Rymes of Robyn Hood: An Edition of the Texts, ca. 1425 to ca. 1600. Medieval and Renaissance Texts and Studies 428. Tempe: Arizona Center for Medieval and Renaissance Studies, 2013.

Ritson, Joseph. Robin Hood, A Collection of All the Ancient Poems, Songs and Ballads Now Extant Relative to the Celebrated English Outlaw. 2 vols. London: Egerton and Johnson, 1795.

Scott, Walter. Ivanhoe. London, Penguin, 1972. 
Smith, Captain Alexander. "Robin Hood." In A Complete History of the Lives and Robberies of the Most Notorious Highwaymen, edited by Arthur L. Hayward, 408-12. London: Routledge, 1926.

Stillinger, Jack, ed. The Poems of John Keats. Cambridge, MA: Harvard University Press, 1978.

Tennyson, Alfred. The Foresters. In Poems and Plays, 748-82. Oxford Standard Authors. Oxford: Oxford University Press, 1965.

Thompson, E. P. Whigs and Hunters: The Origin of the Black Act. London: Allen Lane, 1975.

Trease, Geoffrey. Bows Against the Barons. London: Lawrence, 1934. 